\title{
Ventilasi Mekanik yang Memanjang pada Pasien Cedera Otak Traumatik Berat dengan Kejang Pascatrauma
}

\author{
Sinta Irina*), Bambang J. Oetoro ${ }^{* *}$, Syafruddin Gaus $\left.{ }^{* * *}\right)$ \\ ${ }^{*}$ Departemen Anestesiologi dan Terapi Intensif Fakultas Kedokteran Universitas Sumatera Utara RSUP H. \\ Adam Malik Medan, ${ }^{* *}$ Departemen Anestesiologi dan Terapi Intensif Fakultas Kedokteran Khatolik Atmajaya- \\ Rumah Sakit Mayapada-Tangerang, ${ }^{* * *}$ Departemen Anestesiologi,Terapi Intensif dan Manajemen Nyeri Fakultas \\ Kedokteran Universitas Hasanuddin-Makassar
}

\begin{abstract}
Abstrak
Cedera otak traumatik (COT) masih menjadi masalah di dunia dan merupakan salah satu penyebab utama kematian dan kecacatan pada anak dan orang dewasa. Cedera otak primer dapat mengakibatkan cedera otak sekunder yang akan mempengaruhi hasil luaran. Komplikasi dari COT berat dapat berupa kejang, demam, infeksi paru sebagai cedera sekunder yang akan memperburuk luaran. Seorang laki-laki, 24 tahun, BB $50 \mathrm{~kg}$ dirujuk dari RSUD dengan penurunan kesadaran GCS E1M2V1, hasil CT scan kepala memperlihatkan adanya perdarahan intraserebral di frontal kanan/kiri dan parietal kanan, perdarahan subdural, perdarahan subarachnoid dan edema otak. Pasien segera diintubasi di UGD dan direncanakan dekompresi kraniektomi untuk evakuasi perdarahan. Pada perawatan hari ke 2, pasien sering mengalami kejang dengan durasi yang lama, sehingga penggunaan ventilasi mekanik memanjang dan pasien tidak dapat disapih dari ventilator. Salah satu komplikasi pemakaian ventilator $>48-72$ jam adalah ventilator associated pneumonia (VAP). Diberikan terapi antibiotik sesuai kultur dan penanganan bagi pemulihan paru. Dilakukan tindakan trakeostomi dan pasien dapat disapih dari ventilator pada hari ke-15.
\end{abstract}

Kata kunci: cedera otak traumatik, VAP cedera otak traumatik, ventilasi mekanik memanjang, VAP

JNI 2018;7 (1): 110-16

\section{Prolonged of Mechanical Ventilation in Patients with Severe Traumatic Head Injury with Post Traumatic Seizures}

\begin{abstract}
Traumatic head injury is still a worldwide problem and it's one of the leading causes of death and disability in children and adults. Secondary head injury is a result of primary head injury, which affect the outcome. Complications of severe head injury are seizure, fever, lung infection which ussually makes worst the outcome. In this case report: a man, 24 years old, $50 \mathrm{kgbb}$ in weight was referred from the RSUD with decreased conciousness with score GCS E1M2V1, head CT-scan showed intracerebral hemorrhage on the right and left frontal lobes and right parietal lobe, subdural, subarachnoid hemorrhage and cerebral edema. Patients was immediately intubated in the ER and planned craniectomy decompression for bleeding evacuation. Second day in the ICU, the patient had frequent and long duration of seizures which postponed the weaning from mechanical ventilation. Using mechanical ventilation more than 48-72 hours could developed ventilator associated pneumonia (VAP). Antibiotics given based from the culture results and the lung being treatment. Weaning from ventilator on 15 th day achived after tracheostomy procedure
\end{abstract}

Key words: severe traumatic head injury, prolonge mechanical ventilation, VAP

JNI 2018;7 (1): 110-16 


\section{Pendahuluan}

Cedera kepala masih menjadi masalah utama di dunia dengan angka mortalitas dan morbiditas yang tinggi. ${ }^{1}$ Cedera sekunder pasca cedera kepala berat dapat mempengaruhi tekanan perfusi otak. Di mana diketahui bahwa CPP = MAPICP. Maka bila cedera sekunder bertambah maka ICP akan meningkat dan CPP akan menurun. ${ }^{2}$ Kejang dapat terjadi pasca cedera kepala dan pada pasien yang mengalami kejang seringkali memperlambat penyapihan dari penggunaan ventilasi mekanik. Salah satu komplikasi dari pemasangan ventilasi mekanik lebih dari 48 jam adalah terjadinya Ventilator Associated Pneumonia (VAP). Infeksi ini merupakan komplikasi paling serius di rumah sakit, angka kejadiannya hanya di bawah infeksi saluran kencing terutama di Neurointensive Care. Diagnosa VAP ditegakkan berdasarkan klinis, pemeriksaan foto thoraks, adanya leukositosis dan sekreta trakeobronkial yang purulen. ${ }^{3}$

\section{Laporan Kasus}

\section{Anamnesis}

Seorang laki-laki umur 24 tahun, berat badan $50 \mathrm{~kg}$, dirujuk dari RSUD dengan penurunan kesadaran akibat kecelakaan lalu lintas beberapa jam sebelum masuk rumah sakit. Mekanisme trauma tidak diketahui. Pasien dibawa dengan ambulan didampingi paramedis dan menggunakan $\mathrm{O}_{2}$ masker 5 liter/menit dimana lama perjalanan sekitar 3 jam. Telah terpasang nasogastic tube (NGT) dan kateter urine. Hemodinamik dilaporkan dalam keadaan stabil.

\section{Pemeriksaan Fisik}

Jalan nafas potensial obstruksi, terpasang guedel (oropharyngeal airway). Pasien dengan pernafasan $24 x /$ menit dengan suara nafas normal pada paru kanan dan kiri dan tidak ada ditemui tanda-tanda hematopneumothorax. Tekanan darah 130/80 mmHg dengan nadi 95x/menit, perfusi akral hangat, kering dan merah. Pada pemeriksaan neurologis didapatkan GCS E1M3V1 pupil anisokor $2 / 3$ dengan reflek cahaya positip normal. Tidak ditemukan adanya racoon eyes, battle sign atau pun fraktur basis cranii lainnya.
Penatalaksanaan di Unit Gawat Darurat (UGD)

Setibanya di UGD, langsung dilakukan tindakan intubasi dengan pipa endotrakeal no 7,5 menggunakan teknik inline position karena adanya kecurigaan cedera servikal dan penekanan krikoid untuk pencegahan aspirasi. Obat diberikan secara titrasi dengan mengawasi parameter hemodinamik secara ketat, dan berurutan fentanyl $100 \mathrm{mcg}$ iv, propofol $80 \mathrm{mg}$ iv, rocuronium $50 \mathrm{mg}$ iv, lidokain $60 \mathrm{mg}$ iv dan tambahan propofol $20 \mathrm{mg}$ iv sebelum dilakukan intubasi. Selama periode induksi dan intubasi tekanan darah berkisar 90-130/60-90 mmHg, laju nadi 65-80x/menit. Dilanjutkan dengan propofol kontinyu $30 \mathrm{mg} / \mathrm{jam}$ dan rocuronium 20 $\mathrm{mg} / \mathrm{jam}$ untuk rumatan, paracetamol 1 gram drip, ranitidin $40 \mathrm{mg}$ iv dan mannitol $150 \mathrm{ml}$. Pasca intubasi keadaan hemodinamik pasien stabil dan pasien dibawa ke ruangan radiologi untuk pemeriksaan CT scan kepala dan penunjang lainnya. Selama di IGD dilakukan kontrol ventilasi secara manual dan monitoring tanda vital. Posisi kepala pasien lebih tinggi $30^{\circ}$ tanpa bendungan vena di leher. Pemberian cairan $\mathrm{NaCl}$ 0,9\% diberikan ekstra $500 \mathrm{ml}$ di ruang UGD untuk mencukupi volumenya dan rumatan $2 \mathrm{ml} / \mathrm{kg} / \mathrm{jam}$.

\section{Pemeriksaan Penunjang}

Hasil pemeriksaan CT-scan kepaka memperlihatkan adanya ICH pada regio frontal kanan dan kiri, ICH di regio parietal kanan, SDH, SAH disertai edema otak dan gambaran hernia subfalcin ke arah kiri. Pemeriksaan laboratorium

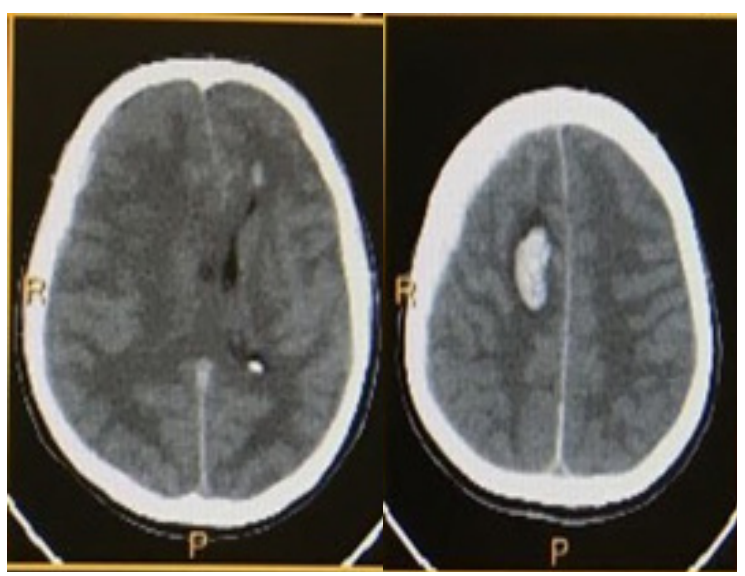

Gambar 1. Scan Kepala Pre op 


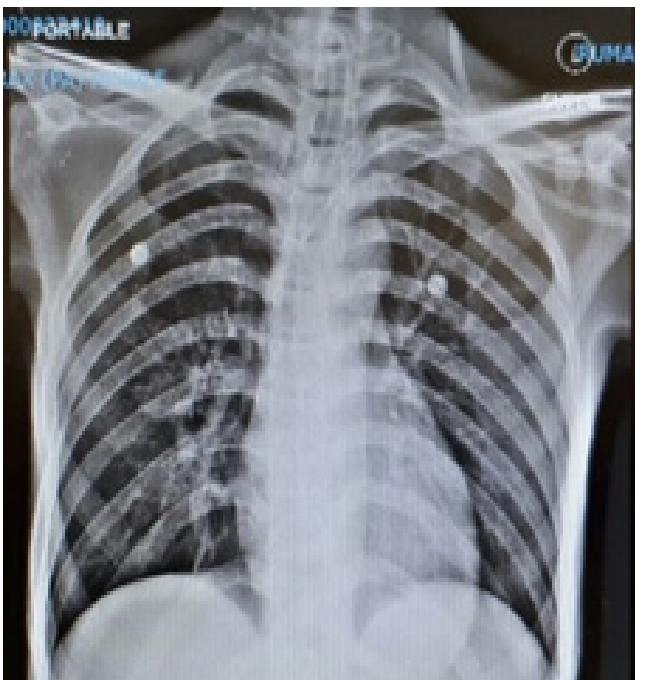

Gambar 2. Foto Thoraks Pre op

didapatkan $\mathrm{Hb}$ 11,9 g/dL, leukosit $23.07 \mathrm{ribu} / \mathrm{uL}$, hematokrit $35,8 \%, 235 \mathrm{ribu} / \mathrm{uL}$, trombosit 250 ribu/mm3, PT 10,5 detik INR 0,89, aPTT 28,5 detik, SGOT 76 U/L, SGPT 65 U/L, ureum $30 \mathrm{mg} /$ $\mathrm{dL}$, kreatinin $0,7 \mathrm{mg} / \mathrm{dL}$, gds $120 \mathrm{mg} / \mathrm{dL}$, Natrium $138 \mathrm{mmol} / \mathrm{L}$, Kalium 3,9 mmol/L, klorida 98 $\mathrm{mmol} / \mathrm{L}$. Pasien segera disiapkan untuk operasi dekompresi kraniotomi dan evakuasi perdarahan.

\section{Pengelolaan Anestesi}

Pasien dilakukan tindakan evakuasi perdarahan intraserebral dan dekompresi kraniektomi. Pasien dipindahkan ke meja operasi dalam keadaan tersedasi dan terintubasi. Posisi kepala head up $15-30^{\circ}$. Dipasang alat-alat monitor non invasif

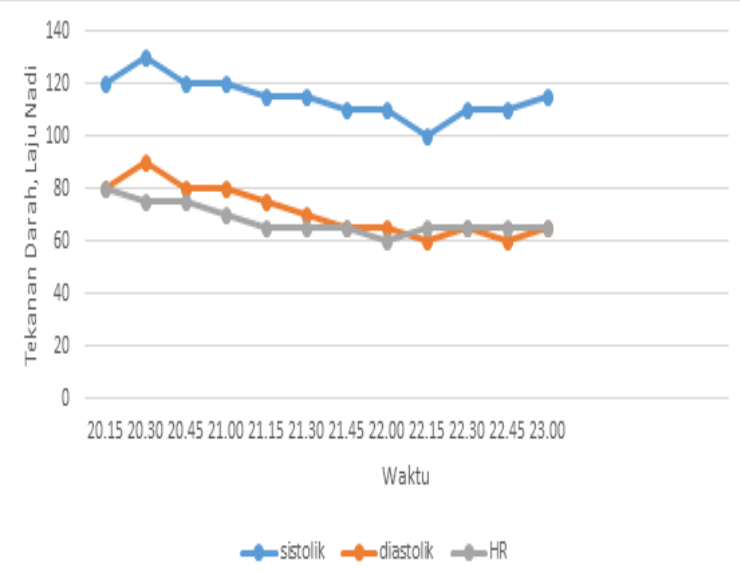

Gambar 3. Hemodinamik selama Pembedahan tekanan darah, denyut jantung, $\mathrm{EKG}, \mathrm{SpO}_{2}$. Pemeliharaan anestesi digunakan sevoflurane $1-1,5 \%-\mathrm{O}_{2}-$ udara, propofol kontinyu $4-6 \mathrm{mg} /$ $\mathrm{kg} / \mathrm{jam}$, rocuronium $20 \mathrm{mg} / \mathrm{jam}$, fentanyl $1-2 \mathrm{mcg} /$ $\mathrm{kg} / \mathrm{jam}$. Operasi berlangsung 2,5 jam, perdarahan $\pm 1700 \mathrm{ml}$, produksi urine $200 \mathrm{ml}$ selama 2,5 jam. Cairan rumatan Ringer solution $1500 \mathrm{ml}$, HES $500 \mathrm{ml}$, PRC $500 \mathrm{ml}$. Hemodinamik selama operasi relatif stabil, tekanan darah sistolik berkisar antara 100-130 mmHg, diastolik $70-90$ $\mathrm{x} /$ menit dengan mean arterial pressure (MAP) rerata $75-95 \mathrm{mmHg}$, laju nadi $60-70 x /$ menit, Saturasi Oksigen 98-99\%.

\section{Perawatan Pascabedah}

Pascabedah pasien tidak diekstubasi dan pernafasan dikontrol dengan ventilasi mekanik, dengan TV $400 \mathrm{ml}$ frekuensi nafas 14x/menit PEEP $5 \mathrm{FiO}_{2} 50 \%$. Dilakukan pemeriksaan analisa gas darah setelah 1 jam pemasangan ventilasi mekanik didapatkan hasil $\mathrm{pH} 7,40$ $\mathrm{pCO}_{2} 38 \mathrm{pO}_{2} 150$ total $\mathrm{CO}_{2} 24,5 \mathrm{BE}-1,0$, saturasi $\mathrm{O}_{2} 99 \%$. Setelah efek relaksan habis dan pasien mulai bernapas spontan, modus ventilator diubah menjadi SIMV RR 12x/menit TV $400 \mathrm{ml}$ PEEP $5 \mathrm{FiO}_{2}$ 0\%. Pasien disedasi analgesi dengan dexmedetomidine $1-2 \mathrm{ml} / \mathrm{jam}$. Analgetik paracetamol $1 \mathrm{gram} / 8 \mathrm{jam}$, ranitidin $2 \times 50 \mathrm{mg}$, ceftriaxone $1 \mathrm{gram} / 12 \mathrm{jam}$. Cairan rumatan diberikan Ringerfundin $2000 \mathrm{ml} / 24 \mathrm{jam}$, mannitol $125 \mathrm{ml} / 4$ jam, phenytoin $1 \mathrm{amp} / 8 \mathrm{jam}$. Hasil laboratorium pasca operasi $\mathrm{Hb} 8,8 \mathrm{gr} / \mathrm{dL}$,

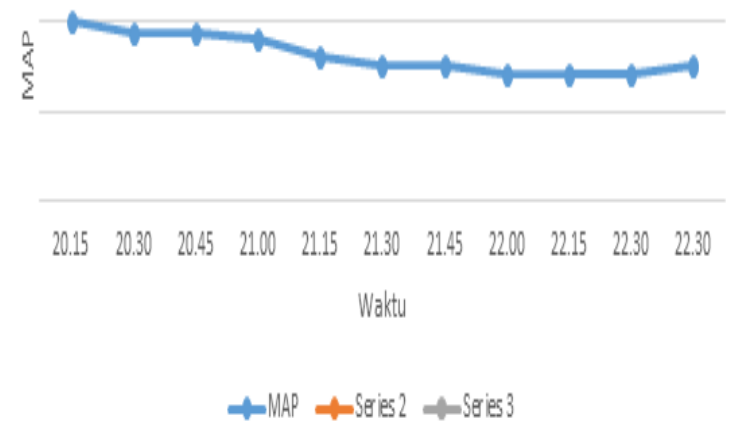

Gambar 4. MAP selama Pembedahan 
leukosit 19.900/mm3, trombosit 258.000/mm3, hematokrit $26.8 \%$, gula darah sewaktu $110 \mathrm{mg} /$ dL.

\section{Perawatan pada hari pertama}

Pasien masih dalam support ventilasi dengan alat bantu nafas mekanik modus SIMV RR 12x/menit, PEEP $5 \mathrm{FiO}_{2} 40 \%$ didapatkan $\mathrm{SpO}_{2}$ 98-99\%. Hemodinamik stabil dengan MAP rerata 80-100 $\mathrm{mmHg}$, lajunadi60-65x/menit.Prosespenyapihan dari ventilasi mekanik sudah mulai dilakukan. Kesadaran pasien masih belum ada perbaikan.

\section{Perawatan hari kedua}

Pasien mengalami kejang, dan takikardi dengan laju nadi 120-140x/menit. Diberikan terapi diazepam bila kejang dan sedasi dinaikkan dosisnya. Obat sedasi analgesi diberikan fentanyl $0,2 \mathrm{mikro} / \mathrm{kg} / \mathrm{jam}$ dan midazolam $0,01 \mathrm{mg} / \mathrm{kgBB} /$ jam. Kejang terjadi beberapa kali dalam sehari. Kejang bersifat seluruh tubuh. Oleh karena sering terjadi kejang maka pasien diberi relaksan rocuronium $20 \mathrm{mg} / \mathrm{jam}$ dan pernapasan kembali dikontrol. Pasien dibawa untuk pemeriksaan ulang CT scan kepala dan pemeriksaan AGD ulang. Didapatkan hasil $\mathrm{pH} 7,39 \mathrm{pCO}_{2} 36,0$ $\mathrm{pO}_{2} 155$ total $\mathrm{CO}_{2} 23,6 \mathrm{BE}-1,5$ saturasi oksigen $99 \%$ dan dilakukan cek ulang elektrolit. Hasil $\mathrm{Na}$ $140 \mathrm{mmol} / \mathrm{L} \mathrm{K} \mathrm{3,6} \mathrm{mmol/L} \mathrm{Cl} 100 \mathrm{mmol} / \mathrm{L}$.

\section{Perawatan Hari ketiga}

Pasien mulai demam temperatur $38-40^{\circ} \mathrm{C}$

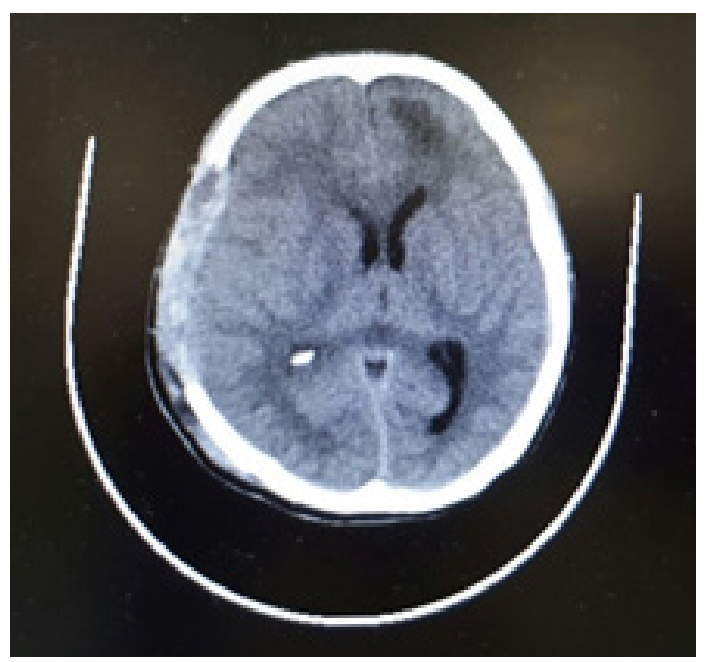

Gambar 5. Head Scan Kontrol walaupun rutin diberikan obat penurun panas paracetamol $1 \mathrm{gr} / 8 \mathrm{jam}$. Dosis paracetamol dinaikkan menjadi 1 gr/6jam, dan pasien diberikan cool blanket. Hemodinamik dalam keadaan stabil. Kesadaran masih belum ada perbaikan. GCS E3M2Vtube, kejang masih tetap ada. Antibiotik diganti menjadi Meropenem 1 gr/8jam. Diambil kultur darah dan sputum

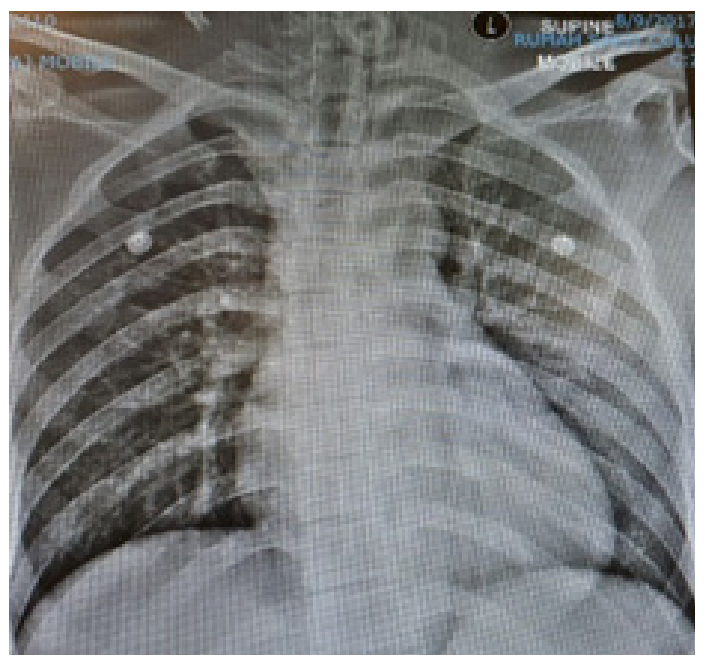

\section{Gambar 6. Foto Thorax hari ke-4}

\section{Perawatan hari keempat sd ketujuh}

Pasien mulai dilakukan penyapihan ventilasi mekanik. Kesadaran pasien meningkat, mulai buka mata namun belum ada kontak. Kejang masih ada terus, demam temperatur berkisar $37-39^{\circ} \mathrm{C}$. Dari hasil kultur sputum didapatkan Staphylococcus aureus dan antibiotik meropenem masih tetap sensitif dengan kultur kumannya. Selama perawatan ICU tetap diberikan dukungan nutrisi yang adekuat $1500 \mathrm{kkal}+60$ gr protein. Balans cairan diawasi ketat. Dilakukan cek laboratorium ulang semua dalam batas normal.

\section{Perawatan minggu ke-2.}

Pasien masih dalam bantuan ventilasi mekanik dengan SIMV rate 12x/menit PEEP $5 \mathrm{FiO}_{2} 40 \%$. Keadaan hemodinamik stabil. Kesadaran belum ada perbaikan dengan GCS E3M2Vtube. Kejang juga tetap masih ada tetapi frekuensi dan durasinya berkurang. Dari hasil pengamatan keadaan pasien dan diskusi dengan tim yang merawat maka diputuskan untuk dilakukan trakeostomi. Dan hari ke-10 pasien dilakukan trakeostomi. Dan 
juga dilakukan bronkoskopi untuk endobronkial toilet. Fisioterapi napas juga tetap dilakukan. Suhu tubuh pasien mulai berangsur turun pada hari ke-10 dengan sejalan menurunnya suhu tubuh maka frekuensi dan lamanya kejang juga berkurang. Pasien lepas dari ventilator hari ke15 namun tetap dengan $\mathrm{O}_{2}$ dan masih dalam perawatan ICU karena masih terjadi kejang. Pada hari ke-25 pasien dilakukan pemeriksaan EEG oleh neurologist. Kesadaran pasien GCS E4M3Vt

\section{Pembahasan}

Patofisiologi trauma kepala melibatkan cedera primer dan sekunder. Beratnya cedera primer akan menentukan luaran pasien dimana adanya cedera primer akan mengawali terjadinya proses inflamasi, terbentuknya edema dan eksotoksisitas yang akan meningkatkan TIK dan menurunkan ADO. ${ }^{1}$ Pada kasus ini, pasien mengalami trauma kepala yang tidak diketahui pasti waktu kejadiannya dan dibawa ke RSUD setempat serta dirujuk ke RS kota dengan waktu perjalanan 4 jam dengan peralatan minimal. Selama 4 jam tersebut dapat terjadi kenaikan TIK akibat hipotensi, hipoksemia, hipokapnia, hiperkapnia, hipertensi yang akan memperberat hasil luaran. Setelah sampai di UGD segera dilakukan intubasi untuk proteksi jalan napas agar jalan napas tetap bebas dan mencegah aspirasi paru, diberikan oksigenasi dan kontrol ventilasi untuk mencegah hipoksia dan hiperkapnea, menjaga status hemodinamik tetap stabil dengan menghindari hipertensi berlebih dan hipotensi yang membahayakan, posisi kepala netral dan head up untuk memastikan aliran darah balik serebral tidak mengalami gangguan, diberikan obat sedasi dan analgesi serta relaksan untuk memfasilitasi penggunaan ventilasi mekanik dan pemberian mannitoldosis $0,5 \mathrm{gr} / \mathrm{kgBB}$ diberikansebagaiusaha untuk mengendalikan tekanan intrakranial. ${ }^{1-2,5,7,8}$

Penatalaksanaan cedera kepala pada saat ini menitikberatkan pada pencegahan dan pengelolaan cedera sekunder. Hal ini dimulai pada awal resusitasi dan stabilisasi, baik pra rumah sakit, unit gawat darurat, proses pemindahan pasien sampai pada evakuasi pembedahan dengan menjaga TIK, menjaga ADO, dan monitoring tanda vital. Minimnya peralatan yang tersedia selama proses transportasi membuat penanganan awal pasien ini tidak maksimal. 1,2,5 Salah satu komplikasi dari trauma kepala adalah kejang. Walaupun hampir kebanyakan penderita trauma kepala tidak pernah mengalami kejang. ${ }^{6}$ Kebanyakan kejang terjadi pada hari pertama hingga beberapa hari pasca cedera kepala. Namun ada yang mengami kejang berbulan-bulan hingga bertahun-tahun pasca terjadinya trauma kepala. Sebanyak $70-80 \%$ penderita yang mengalami kejang dibantu dengan obat-obatan. Fenitoin adalah obat yang diberikan untuk pencegahan dan pengobatan kejang. Kejang setelah cedera kepala trauma dapat diklasifikasikan sebagai yang terjadi pada awal 7 hari atau lambat terjadi yaitu setelah 7 hari. ${ }^{6}$ Pada kasus ini penderita mengalami kejang pada 2 hari pascabedah. Telah diberikan fenitoin sebelum dan setelah pembedahan. Tidak ada data apakah pasien ini ada riwayat kejang di tempat kejadian sebelum dirujuk ke RS kota.

Kejang pascatrauma kepala dapat muncul secara cepat (early) dan lambat (late). Kejang yang cepat muncul pada minggu pertama dan kejang yang munculnya lambat timbul lebih dari 7 hari pascatrauma kepala. Hampir $80 \%$ penderita menderita kejang yang timbul setelah lebih dari seminggu. ${ }^{6,11}$ Pada pasien ini kejang timbul dalam minggu pertama yaitu mulai pada hari kedua pascabedah, dan semakin bertambah frekuensi dan lamanya kejang dengan adanya demam akibat infeksi paru yang didapat. Dengan adanya demam maka kebutuhan konsumsi oksigen otak $\left(\mathrm{CMRO}_{2}\right)$ semakin meningkat dimana tekanan intrakranial juga akan meningkat sehingga terjadi kejang yang lebih sering dan lebih lama. Adanya kejang dan demam akan memperpanjang penggunaan ventilasi mekanik. Ada beberapa faktor resiko terjadinya kejang pascatrauma kepala yaitu adanya hematoma intraserebral akut, hematoma subdural akut, umur yang muda, beratnya cedera, pengguna alkohol yang lama. Pada pasien ini ada beberapa faktor resiko yang didapat yaitu adanya perdarahan intraserebral, umur muda yaitu 24 tahun, dan mengalamitraumakepalaberatdengan skorGCS 5. Kejang pascatrauma kepala dapat menjadi kompikasi serius. Kejang ini dapat menjadi 
penyebab kerusakan otak dengan meningkatkan kebutuhanmetabolik, kenaikanTIK, hipoksia otak, dan lepasnya neurotransmitter.Penanganankejang bisa dengan obat benzodiazepine yang merupakan pilihan obat pertama, kemudian fenitoin. Pemberian diberi fenitoin akan maksimum secara parenteral $50 \mathrm{mg} /$ menit. $^{6}$ Pada pasien ini pada awalnya diberikan sedasi dengan dexmedetomidine, namun setelah terjadi kejang obat sedasi analgesi diganti dengan fentanyl dan midazolam. Dan juga telah diberikan phenytoin dari sebelum perawatan di ICU untuk mencegah terjadi kejang.

Trauma kepala berat disertai kejang dengan frekuensi sering dan durasi lama maka penyapihan dari alat ventilasi mekanik pun tidak bisa berlangsung cepat. Pemakaian ventilasi mekanik lebih dari 48 jam akan mengakibatkan ventilator associated pneumonia (VAP). Setelah dicurigai terjadinya VAP maka segera dilakukan foto thoraks ulang, kultur sputum dan penggantian antibiotik sesuai dengan peta kuman pada ICU tersebut. Dan dilakukan perawatan paru dengan bronkoskopi untuk endobronkial toilet dan fisioterapi nafas. Ventilator associated pneumonia merupakan pneumonia yang terjadi setelah 48-72 jam dilakukan intubasi ditandai dengan adanya infiltrat secara progresif, tanda dan gejala klinis infeksi (demam, kenaikan leukosit), perubahan sputum. Ventilator associated pneumonia berkontribusi hampir 50\%darisemuapenyebabhospital acquired pneumonia. Angka VAP paling besar pada lima hari pertama. Dan resiko menurun $2 \%$ per hari pada 5-10 hari perawatan ventilasi mekanik dan $1 \%$ per hari setelahnya. Angka mortalitas pada VAP 33-50\%, namun angka ini bervariasi sesuai dengan penyakit yang mendasarinya. Hampir $50 \%$ antibiotik yang diberikan di ICU digunakan untuk mengobati VAP. ${ }^{9,10,12}$ Pada pasien ini semua gejala klinis menunjukkan arah ke VAP. Adanya demam, sekret purulen, leukositosis dan terjadi pada hari ke-4 dan gambaran foto thoraks infiltrat. Trakeostomi dilakukan pada hari ke-10 mengingat kesadaran pasien tidak terlalu baik untuk melindungi jalan napas dan mempercepat proses penyapihan dari ventilator. Bronkoskopi sebagai endobronkial toilet dilakukan untuk mengeluarkan sumbatan sekret jalan nafas dan memperbaiki proses oksigenasi. Kuman patogen penyebab VAP berdasarkan frekuensi serta kemungkinan terjadinya multi drug resistance (MDR) adalah: Pseudomonas (24,4\%), S. Aureus (20,4\%), Enterobacteriaceace $(14,1 \%)$, Streptococcus species (12,1\%), Haemophilus sp (9,8\%). Pada kultur sputum pasien ini didapatkan Staphylococcus aureus, dan dilakukan penghitungan The Clinical Pulmonary Infection Score (CPIS) adalah 8. Namun dengan penggantian antibiotik meropenem 1 gram/8jam sesuai dengan kultur didapatkan hasil yang membaik. ${ }^{9}$

\section{Simpulan}

Penanganan trauma kepala berat perlu dilakukan secara optimal sejak dari awal kejadian dan untuk mencegah terjadi cedera otak sekunder yang akan memperberat luaran. Kejang dan demam merupakan cedera sekunder yang mempengaruhi hasil luaran. Penanganan yang dilakukan pada kasus ini meliputi tatalaksana jalan nafas dan sistem respirasi, optimalisasi hemodinamik, pengendalianTIKdantindakanlainyangdiperlukan untuk menjaga perfusi dan oksigenasi serebral.

\section{Daftar Pustaka}

1. Curry P, Viernes D, Sharma D. Perioperative management of traumatic brain injury. Int $\mathrm{J}$ Crit Illn Inj Sci. 2011.

2. D Judith. Traumatic brain injury an evidencebased review of management. Cont Educ in Anesth Crit Pain. 2013; 13: 6.

3. Koenig S, Truwit J. Ventilator-associated pneumonia: diagnosis, treatment, and prevention. Clinical Micro Rev.2006: 637-57

4. Minei P, Nathers B. Guidelines for prevention, diagnosis and treatment of ventilator associated pneumonia in the trauma patient. J Trauma. 2006; 60: 1106-13

5. Haddad S, Arabi YM. Critical care management of severe traumatic brain injury in adults. SJTREM. 2012; 20: 12. 
6. Gilmore R. Seizure. Dalam: Layon A, Gabrielli A, eds. Textbook of neurointensive care 2004: 733-43.

7. Gopinath SP, Robertson CS. Management of severe head injury, Dalam: Cotrell JE, Smith DS, eds Anesthesia and Neurosurgery, USA: Mosby Inc, 2001: 663-85.

8. Bendo A. Perioperative management of adult patients with severe head injury, Dalam: Cotrell JE, Young WL, eds Cotrell and Young's Neuroanesthesia, USA: Mosby Inc, 2010: 317-28.
9. Kalanuria A, Zai W. Ventilator-associated pneumonia in the ICU. Biomed Central 2014: 2-7.

10. DA Zygun, DJ Zuege. Ventilator-associated pneumonia in severe traumatic brain injury, Neurocrit care 2006;5(2):108-14.

11. Englander J, Cifu D. Seizures after traumatic brain injury. Arch Phys Med Rehabil. 2014; 95(6): 1223-7.

12. Murthy TVSP, Bhatta P. Secondary brain injury: prevention and intensive care management, IJNT 2005; 2(1): 7-12. 